\title{
NAZAJ K EVROPI - GEOPOLITIČNI DISKURZI O SREDNJI IN VZHODNI EVROPI V INSTITUCIJAH EVROPSKE UNIJE
}

\author{
Boštjan Rogelj \\ Oddelek za geografijo, Filozofska fakulteta Univerze v Ljubljani, Aškerčeva cesta 2, \\ SI - I000 Ljubljana, Slovenija \\ e-mail: bostjan.rogelj@ff.uni-lj.si
}

Izvirni znanstveni članek

COBISS 1.01

\section{Izvleček}

Kritična geopolitika obravnava geopolitiko kot diskurzivni postopek, s pomočjo katerega različni akterji prostorizirajo mednarodno politiko. Hitro spreminjanje geopolitičnih razmer so po končani hladni vojni Evropsko unijo prisilile k oblikovanju vedno novih prostorizacij evropskega kontinenta. V ospredju le-teh sta "širitev Evrope" na vzhod in z njo povezano oblikovanje novih meja "Evrope".

Ključne besede: geopolitika, Evropska unija, Srednja in Vzhodna Evropa, geografija.

\section{BACK TO EUROPE - GEOPOLITICAL DISCOURSES ABOUT CENTRAL AND EASTERN EUROPE INSIDE INSTITUTIONS OF EUROPEAN UNION}

\begin{abstract}
Critical geopolitics understands geopolitics as a set of discursive practices by which different actors spatialize international politics. Wast changes in geopolitical settings after the end of Cold war have forced European Union in constant shaping and reshaping of new spatializations of European continent. In the forefront of this new representations are eastern "enlargement of Europe" and shaping of new borders of "Europe".

Key words: Geopolitics, European Union, Central and Eastern Europe, Geography.
\end{abstract}




\section{UVOD}

Prvega maja 2004 smo bili priča zgodovinski širitvi Evropske unije na deset novih držav. Datum simbolično označuje konec pomembnega obdobja v zgodovini Evrope. Obdobja, ki je po štiridesetih letih relativne stabilnosti prineslo velike spremembe v geopolitično podobo kontinenta. Razpad komunističnih sistemov v Srednji in Vzhodni Evropi je dokončno pokopal staro bipolarno delitev sveta. Nove razmere so povzročile preoblikovanje starih oziroma oblikovanje novih »prostorizacij« sveta. V njih so posamezni akterji poskušali razložiti na novo nastale (geo)politične razmere ter redefinirati vloge na mednarodnem prizorišču. Izguba tradicionalnih vlog in z njo povezana kriza identitete sta akterje prisilili, da so ponovno določili svojo vlogo v svetu. Večina si je prizadevala, da bi dobila čim pomembnejšo vlogo na regionalnem oziroma globalnem prizorišču. Evropska Unija pri tem ni bila izjema. V novih razmerah je videla priložnost, da se na mednarodni politični sceni postavi ob bok Združenim državam Amerike.

V središču zunanjepolitičnih ambicij Evropske unije sta se znašli Srednja in Vzhodna Evropa. Politična in gospodarska tranzicija nekdanjih komunističnih držav ter njihova vključitev v evropske integracijske procese so predstavljali zgodovinsko priložnost za Evropsko unijo (glej Evropska komisija, 1992). Unija naj bi na eni strani delovala kot zgled državam v tranziciji, hkrati pa bi jim s svojo politično, tehnično in ekonomsko podporo pomagala čim hitreje in čim uspešneje izpeljati potrebne reforme.

Nove razmere, vključno $\mathrm{z}$ novim poslanstvom, so oblikovale novo prostorizacijo kontinenta. V ospredje so bili postavljeni novi kraji in dogodki, ki so zahtevali opustitev uveljavljenih ter oblikovanje novih terminov oziroma označb. Opozoriti je treba, da ta proces preoblikovanja uveljavljenih predstav o svetu ni bil enkraten. Številni dogodki in procesi znotraj Unije ter na globalnem političnem prizorišču so jo prisilili, da je nenehno popravljala in preoblikovala omenjene predstave.

\section{I.I Teoretska in metodološka izhodišča}

Prispevek temelji na teoretskih izhodiščih kritične geopolitike. Le-ta geopolitike ne obravnava kot nevtralno in objektivno prakso proučevanja globalnega prostora, ampak kot družbeno, kulturno in politično prakso (O’Tuathail, Dalby, 1998, 2). Po mnenju Ó Tuathaila (1996) je geopolitika diskurzivni postopek, s pomočjo katerega različni akterji prostorizirajo mednarodno politiko. Pojem prostorizacija (ang. spatialization) označuje diskurzivno prakso, s pomočjo katere posamezniki in družbene skupine predstavljajo oz. prikazujejo svet na določen način. Prek prostorizacije svet postane prostor, zaznamovan z določenimi tipi krajev, ljudi in dram. Geopolitika ni neproblematičen opis svetovne politične karte, temveč razprava, kulturno in politično spreminjajoč se način opisovanja, prikazovanja in pisanja o geografiji in mednarodnih odnosih. Kritična geopolitika problematizira, kako geografski diskurz in sistem oblasti delujeta drug prek drugega ter projicirata karte globalne politike $\mathrm{z}$ domačimi centri in tujimi periferijami, jedrnimi identitetami in marginalnimi prostori, pokornimi regijami in nemirnimi conami (O’Tuathail, Dalby, Routledge, 1998; Ó Tuathail, 1994). V središču njenega proučevanja so načini, s katerimi različni geografski diskurzi, prakse in perspektive 
merijo, opisujejo in ocenjujejo svet (Doods, 2005).

Predstavniki kritične geopolitike opozarjajo, da geopolitika ni ločena in relativno zadržana aktivnost, omejena na ozek krog ljudi, ampak zelo širok družben in kulturni fenomen - govoriti o mednarodni politiki pomeni zaplesti se v geopolitiko. (O'Tuathail, Dalby, 1998). Geopolitično mišljenje lahko razdelimo na praktično, formalno in popularno. Prvo se nanaša na prostorizacijske postopke različnih državnih uslužbencev, ki se ukvarjajo z vsakodnevnim izvajanjem zunanje politike. Drugo se nanaša na prostorizacijske postopke strategov in intelektualcev, ki so zaposleni v različnih organizacijah civilne družbe in oblikujejo različne strateške študije o mednarodnem prostoru. Popularna geopolitika pa se nanaša na prostorizacijske postopke v različnih popularnih medijih (O’Tuathail, Dalby, 1998).

Takšno spremenjeno razumevanje geopolitike je osnova pričujočega prispevka. Namesto da bi geopolitiko obravnavali kot nekaj samoumevnega, naravnega, neodvisnega, bomo nanjo gledali kot na problem prostorizacije globalnega prostora s strani različnih družbenih skupin. Zanimalo nas bo, kako nekateri organi Evropske unije (Evropski svet, Ministrski svet ter Evropska komisija) prostorizirajo območje Srednje in Vzhodne Evrope. Kakšne predstave so pri tem oblikovali? Kaj je vplivalo na njihov nastanek? Zakaj se nenehno spreminjajo? Kakšen vpliv imajo na politiko Evropske unije do omenjenega območja?

Drugo teoretično izhodišče, na katerem temelji prispevek, je konstruktivistično dojemanje oblikovanja identitet, v središču katerega je družbeno konstruiranje identitet. Po mnenju Campbella (1998, str. 9) je identiteta nepogrešljiva dimenzija bivanja. Nihče ne more obstajati brez nje. Kljub svoji nepogrešljivosti identiteta - pa naj bo osebna ali kolektivna - ni fiksna, ni nekaj naravnega, ni dana od Boga ali pa zamišljena z namernim vedenjem. Identiteta se oblikuje v odnosu do razlik. Vendar tudi te niso naravne, dane od Boga ali zamišljene z namernim vedenjem, temveč so oblikovane v odnosu do identitete. Zato problematika identitete/razlik ne vsebuje nobenih osnov, ki bi bile predhodne ali pa zunaj njenega delovanja. Oblikovanje identitet se doseže s pomočjo meja, ki služijo kot razmejitev med znotraj/zunaj, jaz/on, domač/tuj.

Isti avtor opozarja na ugotovitve novejših raziskav identitet in držav, ki so pokazale, da so države pogosto nastale pred narodom ter da je nacionalizem državni konstrukt, s katerim leta legitimira svoj obstoj (Campbell, 1998). Narodi so le zamišljene skupnosti, katerih identiteta se oblikuje prek različnih praks (Anderson, 2003).

Takšno razumevanje identitet nujno zahteva rekonceptualizacijo vloge in pomena zunanje politike. Konvencionalno dojemanje mednarodnih odnosov in zunanje politike temelji na predpostavki, da države obstajajo v anarhičnem svetu, zunanja politika pa predstavlja most med njimi, oziroma da je zunanja politika navzven usmerjena praksa. Temu pogledu nasprotuje kritični pristop, ki zunanjo politiko smatra le za integralni del diskurzov o nevarnosti, ki služijo za discipliniranje države - zunanja politika je le ena izmed praks, s katerimi države oblikujejo in ohranjajo lastno identiteto, je ustvarjalka meja in ne mostov (Campbell, 1998).

V skladu s to teorijo Evropska unija s pomočjo skupne zunanje in varnostne politike - katere najpomembnejši del je širitveni proces - konstruira in ohranja lastno identiteto. Skozi zunanjepolitične diskurze EU določa, kaj je Evropska unija, kdo so njeni prebivalci, kje so njene meje, itd... To je eden glavnih razlogov, zakaj nam številni zunanjepolitični diskurzi Unije pogosto povedo več o njej kot o območju, o katerem govorijo. 
V prispevku izhajamo iz proučevanja različnih dokumentov Evropske komisije (European commission), Evropskega sveta oziroma Ministrskega sveta (The Council of the European Union) ki jih najdemo v podatkovni bazi RAPID NG DATABASE (http://europa. eu.int/rapid). Slednja obsega vsa sporočila za javnost omenjenih organov po letu 1985 . V prispevku je zajetih več kot 900 dokumentov iz obdobja od januarja 1989 do decembra 2005. Dokumenti so razdeljeni v štiri skupine: govori (Speeches), deklaracije (Declarations), zapisniki sestankov sveta ministrov za zunanje zadeve (Council meeting - External Relations) in sklepi srečanj Evropskega sveta (European Council Conclusions). Iz naštetega je razvidno, da se raziskava omejuje na proučevanje t.i. praktične geopolitike Evropske unije, medtem ko oblikovanje različnih predstav v sklopu formalne in popularne geopolitike vanjo ni zajeto.

Teritorialno gledano je raziskava omejena na države, ki so bile v času komunizma del t.i. Vzhodne Evrope (Albanija, Bolgarija, Bosna in Hercegovina, Češka, Hrvaška, Madžarska, Makedonija, Poljska, Romunija, Slovaška, Slovenija, Srbija in Črna gora), pri čemer so izmed držav nastalih na ozemlju nekdanje Sovjetske zveze obravnavane le baltske države (Litva, Latvija in Estonija). Omenjeno območje je po letu 1989 doživelo številne politične, ekonomske in socialne spremembe. Dinamičnost procesov in njihovo različno dojemanje - tako znotraj regije, predvsem pa zunaj nje - je sprožilo nastanek številnih geopolitičnih prostorizacij ter z njimi povezanih poimenovanj regije. ${ }^{1} \mathrm{~V}$ prispevku so podrobneje predstavljene tiste oznake, ki so uporabljene v dokumentih Evropske unije.

\section{I.2 Geopolitika Evropske unije}

Preden se lotimo proučevanja različnih predstav, s katerimi Evropska unija prostorizira svet, moramo odgovoriti na ključno vprašanje: Ali sploh obstaja geopolitika Evropske unije? Vemo, da obstajajo geopolitike posameznih članic, toda ali lahko govorimo o geopolitiki Evropske unije?

Formalnopravno lahko govorimo o geopolitiki Evropske unije šele po letu 1992 oziroma po uveljavitvi Maastrichtske pogodbe $\mathrm{z}$ dne 1. 11. 1993. Z njenim sprejetjem sta se začela proces politične integracije Evropske gospodarske skupnosti in njena preobrazba v Evropsko unijo. Ta je temeljila na treh stebrih: ekonomski in monetarni uniji, skupni zunanji in varnostni politiki ter policijskem in sodnem sodelovanju v kazenskih zadevah (Boden, 2004). Za oblikovanje geopolitike Evropske unije je bil posebno pomemben drugi steber, ki so ga leta 1997 dodatno okrepili z Amsterdamsko pogodbo, s katero je bil uveden položaj visokega predstavnika za skupno zunanjo in varnostno politiko. Skupna zunanja in varnostna politika je predvidevala poenotenje politik držav članic in skupen nastop na zunanjepolitičnem področju. Prevedeno v jezik kritične geopolitike - skupna zunanja in varnostna politika predvideva oblikovanje enotne prostorizacije sveta oziroma poenotenja predstav o sebi in svetu. Pred Maastrichtsko pogodbo je bila Unija (takrat še EGS) le gospodarska povezava brez političnih ambicij in želje po enotni geopolitiki, z njo je želela postati pomemben akter na mednarodnem političnem prizorišču.

\footnotetext{
${ }^{1}$ O problematiki poimenovanja omenjenega prostora glej Tunjić (2004) in Mally (2005).
} 
Za razumevanje geopolitičnih diskurzov v Evropski uniji se je treba zavedati dveh dejstev: prvič, Evropska unija ni nadomestek nacionalnih držav, temveč nekakšna nadgradnja oziroma kot pravi Berzin (2003), supranacionalni politični projekt. Drugič, Unija je bila in ostaja projekt političnih elit brez sodelovanja širšega prebivalstva (Lorenci, 2005). Ideja o Evropski uniji je nastala $\mathrm{v}$ glavah peščice politikov, ki so določili glavne smernice njenega razvoja.

Glavni problem skupne zunanje in varnostne politike - sprejete z Maastrichtsko pogodbo - je bilo določilo, ki je predvidevalo soglasje vseh članic pri sprejemanju najpomembnejših zunanjepolitičnih odločitev. ${ }^{2}$ Interesi posameznih članic so zelo različni in si pogosto nasprotujejo, kar pogosto otežuje sprejemanje skupnih odločitev. Zato so politiki prisiljeni sprejemati odločitve na podlagi najmanjšega skupnega imenovalca. Takšen način je resna ovira za aktivnejše delovanje Unije na globalnem prizorišču. ${ }^{3}$ Enako velja tudi za geopolitične predstave. Različne prostorizacije in z njimi povezane predstave je treba na evropski ravni uskladiti in oblikovati v enotno prostorizacijo, ki jo načeloma podpirajo vse članice.

Projekt Evropske unije nastaja od zgoraj navzdol (Debeljak, 2004). Posledica takšnega razvoja sta pomanjkanje ljudske identifikacije z Unijo in neobstoj evropske javnosti ali demosa kot prepoznavne kategorije (Passi, 2005). V Uniji prihaja do velikih razlik med geopolitičnimi predstavami vodilnih elit in širšo javnostjo. ${ }^{4} \mathrm{~V}$ preteklosti predstave evropske javnosti (demosa) niso imele večjega vpliva na razvoj geopolitičnih prostorizacij Evropske unije. Z zavrnitvijo evropske ustavne pogodbe v Franciji in na Nizozemskem se je njihov vpliv povečal. $V$ prihodnosti bodo politične elite prisiljene v večji meri upoštevati mnenje in poglede javnosti. Nova evropska komisija pod vodstvom José Manuela Barrosa je takoj po zavrnitvi ustavne reforme začela govoriti, da sta nujna notranja konsolidacija in širši dialog med Unijo in njenimi državljani (glej: Rehn, 2005; Barroso, 2005).

\section{GEOPOLITIČNE PROSTORIZACIJE EVROPSKE UNIJE PO HLADNI VOJNI}

Evropa je v zadnjih dveh desetletjih doživela številne politične, ekonomske in družbene spremembe. Njihov vpliv je bil največji v t.i. Vzhodni Evropi, kjer je prišlo do korenitega pretresa v družbeno-gospodarskem ustroju vseh držav. Tranzicija iz enopartijskega v večstrankarski sistem, uvedba tržnega gospodarstva, dezintegracija nekaterih držav in

\footnotetext{
${ }^{2}$ Z Amstredamsko pogodbo je sistem odločanja postal učinkovitejši, saj za sprejemanje odločitev ni več potrebno soglasje vseh članic, ampak kvalificirana večina glasov (Portal Evropske unije, 2006).

${ }^{3}$ Politika EU do vojne v Bosni in Hercegovini je eden najboljših primerov, kako lahko nasprotovanje nekaterih članic (v tem primeru Francije in Velike Britanije) onemogoči aktivnejšo vlogo Unije v mednarodni politiki.

${ }^{4}$ Kako velike so razlike med predstavami javnosti in političnih elit je pokazal referendum o sprejetju evropske ustavne pogodbe v Franciji. Razpravo, ki se je razvila v času predreferendumske kampanje, so obvladovale med prebivalstvom globoko zakoreninjene predstave o revnem, nerazvitem Vzhodu in nevarnem Islamu. Prizadevanja vodilnih predstavnikov Unije in Francije, da bi širitev predstavile kot združevanje na silo ločenega kulturnega prostora, ki bo koristila celotni Evropi, niso bila uspešna.
} 
globalizacija so radikalno spremenile podobo vzhodnega dela kontinenta. Na Zahodu so bile spremembe manjše, vendar ne zanemarljive, njihov najpomembnejši rezultat pa sta bili konsolidacija in razširitev Evropske unije (Evropske gospodarske skupnosti).

Nove regionalne in globalne politične, ekonomske in družbene razmere so različne akterje v Evropski uniji in državah članicah prisilile k oblikovanju nove slike sveta. Spremenjene razmere so zahtevale oblikovanje nove oziroma preoblikovanje stare prostorizacije sveta.

\section{I "Druga" Evropa}

Geopolitična prostorizacija Evrope med hladno vojno je bila zelo preprosta. Železna zavesa, ki je potekala od Szczecina na Baltiku do Trsta na Jadranu, je Evropo delila na vzhodni in zahodni del. V vzhodni del so sodile vse države, ki so bile politično, ekonomsko in vojaško bolj ali manj odvisne od Sovjetske zveze. Preostali del kontinenta je pripadal t.i. Zahodni Evropi, ki je bila vojaško in politično - v manjši meri pa tudi ekonomsko - odvisna od Združenih držav Amerike. Srednja oz. Vmesna Evropa je izginila. Samo tri države (Finska, Avstrija in Jugoslavija) so ohranile vlogo tamponske cone med Vzhodom in Zahodom, pa še za slednje je veljalo, da so se bolj ali manj navezovale na enega od močnih sosednjih političnih blokov (Cohen, 1973).

Bipolarna prostorizacija Evrope se je močno zakoreninila $\mathrm{v}$ evropsko miselnost, mnogi so menili, da gre za trajen sistem, ki ga lahko spremeni le vojna ali postopen prehod v nov univerzalni sistem (Simoniti, 1997). Preprosta razumljivost, predvidljivost in relativna stabilnost so pripomogle k njegovi prevladi v različnih geopolitičnih diskurzih. Omenjeni delitvi so najbolj nasprotovali nekateri disidenti iz vzhodnoevropskih držav, ki so opozarjali, da je delitev vsiljena in nepravična do srednjeevropskih narodov. Konrad (1988) v svoji knjigi Antipolitika razočarano ugotavlja, da je štiridesetletna prisotnost sovjetskih čet v Vzhodni Evropi postala za Zahod popolnoma razumna in sprejemljiva ter da v Evropi nima nihče obsežne mirovne strategije, ki bi spremenila obstoječi položaj.

Veliko "zaslugo" za močno zakoreninjenost hladnovojne prostorizacije sta imeli tudi obe velesili, ki sta jo uporabljali za utrjevanje vodilnega položaja v svetu, nadzorovanje zaveznikov

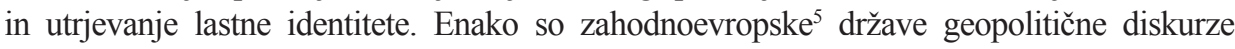
uporabljale za oblikovanje in utrjevanje lastnih nacionalnih ter skupne, "evropske" identitete. Njihovo razumevanje Evrope in "evropskosti" je močno vplivalo na politiko Evropske unije do vzhodnoevropskih držav tudi po padcu komunizma. Nekateri pogledi, oblikovani v tem obdobju, so še danes močno prisotni $\mathrm{v}$ razpravah o evropski identiteti. Najpomembnejša med njimi je trditev, da Zahodna Evropa predstavljala "pravo Evropo" (Murphy, 2005). V Severni Ameriki in Zahodni Evropi se je utrdilo prepričanje, da Vzhodna Evropa ni Evropa, temveč "druga (neprava) Evropa". Debeljak (2004, str. 27) trdi, da si je Zahodna Evropa s pomočjo političnih ustanov hladne vojne in kulturnih mehanizmov za produkcijo smisla $\mathrm{v}$ zadnjih petdesetih letih postopno uspela uzurpirati zgodovinsko idejo Evrope kot celote. Tako

\footnotetext{
5 Tudi vzhodnoevropske države so enako kot njihove zahodnoevropske konkurentke uporabljale železno zaveso kot mejo med "nami" in "njimi" ter z njeno pomočjo producirale in reproducirale lastno identiteto.
} 
je Zahod postal tisti, ki je določal, kaj je Evropa in kaj evropsko. Takšen pogled je močno prisoten tudi danes, ko Evropska unija določa, kaj so evropski temelji in vrednote, kakšno vedenje je "evropsko", itd...

Prostorizacije Evrope, ki so se oblikovale v tem obdobju, so bile pod močnim vplivom bipolarne delitve. Poleg tega je nanjo vplivalo dejstvo, da je bila Evropska gospodarska skupnost (EGS) predvsem organizacija za gospodarsko sodelovanje brez večjih zunanjepolitičnih ambicij. Posledično je EGS Evropo prostorizirala na podlagi ekonomskih odnosov, ki jih je imela s posameznimi državami. Razlike so pripeljale do delitev znotraj obeh blokov (glej karto 1). Zahodna Evropa se je delila na države članice EGS in države članice EFTA. V Vzhodni Evropi je posebno mesto pripadlo Jugoslaviji, ki edina od vzhodnoevropskih držav ${ }^{6}$ ni bila polnopravna članice Sveta za vzajemno gospodarsko sodelovanje (SEV oz. COMECON) in je zato lahko že leta 1970 sklenila dvostranski trgovinski sporazum z EGS?

\subsection{Nazaj k “Evropi”}

Razpad komunističnih režimov in dezintegracija Jugoslavije sta podrli bipolarno podobo Evrope. Politične elite so se zavedale zgodovinskosti dogodka. V Evropi so oživele ideje o pomembnejši vlogi evropskih držav na mednarodnem političnem prizorišču. Mnogi so menili, da je Evropa po štiridesetih letih končno dobila priložnost, da stopi iz sence Združenih držav Amerike in Sovjetske zveze. Vključitev nekdanjih vzhodnoevropskih držav v zahodnoevropske integracijske tokove oz. njihova vrnitev v "Evropsko družino" (Evropska komisija, 1992a) naj bi bila njen prvi pomembni zunanjepolitični preizkus.

Zaradi zunanjepolitičnih ambicij je bilo treba preoblikovati Evropsko gospodarsko skupnost. Strategijo napredovanja korak za korakom je nadomestila strategija velikega poka, ki je predvidevala hkratno uvedbo gospodarske, denarne in politične unije. Politične spremembe v Srednji in Vzhodni Evropi tako niso prinesle spremembe le v omenjeni regiji ampak so močno pospešile evropski integracijski proces ter oblikovanje skupne zunanje in varnostne politike Evropske unije (Baron, 2002).

Nov politični položaj je zahteval novo prostorizacijo Evrope (Slika 1). Oznako Vzhodna Evropa - ki je bila zaznamovana z negativno konotacijo, saj je označevala "drugo" Evropo - je nadomestil termin Srednja in Vzhodna Evropa (ang. Central and Eastern Europe). Novi termin ni bil nikjer geografsko natančno opredeljen. Iz različnih dokumentov, iz obdobja 19881991, lahko sklepamo, da je regija obsegala: Vzhodno Nemčijo ${ }^{8}$, Poljsko, Češkoslovaško, Madžarsko, Romunijo, Bolgarijo in Albanijo (Evropski svet, 1989, 1990a, 1990b). Jugoslavija je imela poseben položaj, saj so jo včasih obravnavali kot del Srednje in Vzhodne Evrope včasih pa kot ločeno enoto (Evropski svet 1989, 1990a). Po razpadu Sovjetske zveze in razglasitvi neodvisnosti baltskih držav se k Srednji in Vzhodni Evropi prištevajo tudi slednje

\footnotetext{
${ }^{6}$ Albanija je leta 1961 prenehala sodelovati v aktivnostih organizacije, vendar uradno iz nje ni nikoli izstopila.

${ }^{7}$ Druge socialistične države niso smele sklepati bilateralnih odnosov z EGS, saj je Sovjetska zveza menila, da je EGS le ekonomska veja zveze NATO (de Clercq, 1987).

${ }^{8}$ Po združitvi postane Vzhodna Nemčija del Evropske unije in s tem del Zahodne Evrope.
} 
Karta 1: Prostorizacija Srednje in Vzhodne Evrope v dokumentih Evropske unije (Evropske gospodarske skupnosti) v obdobju 1987-1996.

Figure 1: Spatialization of Central and Eastern Europe in the documents of European Union (European Economic Community) from 1987 till 1996.

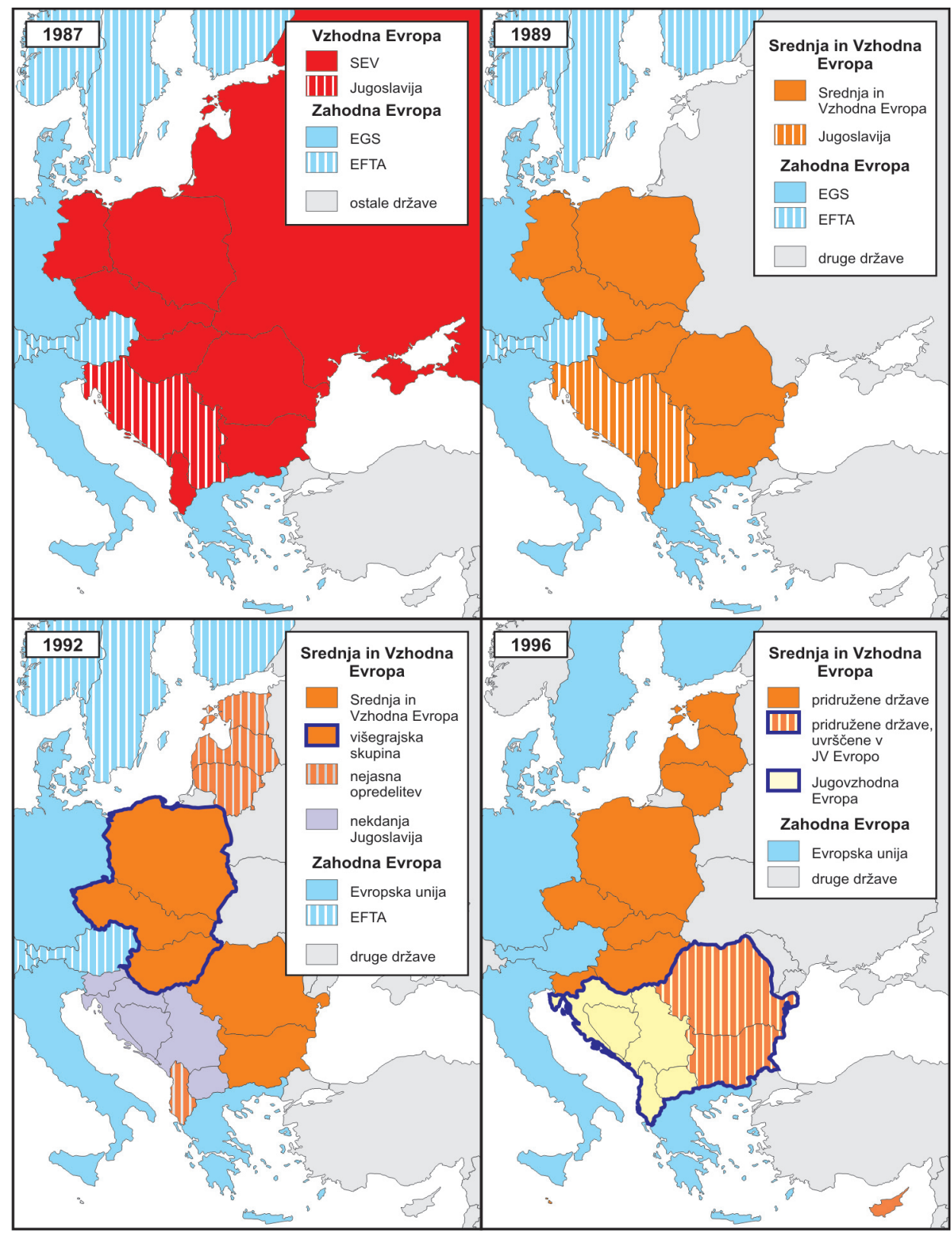


(Evropski svet 1992), medtem ko so imele članice Skupnosti neodvisnih držav (Ukrajina, Belorusija, Moldavija in Rusija) poseben status.

Naštete države so bile na poti "vrnitve v Evropo". Da bi postale "evropske", so morale prevzeti politično in gospodarsko ureditev zahodnoevropskih držav. Uvedba tržnega gospodarstva, izpeljava demokratičnih volitev, spoštovanje pravne države, človekovih pravic in pravic manjšin so bili nujno potrebni za ponovno priključitev k "Evropi". Omenjene zahteve so temeljile na dveh predpostavkah: 1. zahodni politični in ekonomski liberalizem je najboljša in najnaprednejša družbena ureditev"; 2. zahodne države v celoti izpolnjujejo omenjene zahteve. Ti dve tezi sta še danes močno prisotni v geopolitičnih diskurzih Evropske unije in odločilno vplivata na njeno zunanjo politiko. Unija se v svetu pogosto predstavlja kot zvezda vodnica, kot ideal, h kateremu bi morale stremeti druge države, zelo redki pa so samokritični pogledi.

Razlike v hitrosti in uspešnosti gospodarske in politične tranzicije v posameznih državah so kmalu zahtevale novo prostorizacijo. Srednja in Vzhodna Evropa se je razdelila na dva dela. V prvem so države, kjer prehod v demokracijo in tržno gospodarstvo uspešno napreduje, v drugem pa tiste, kjer je tranzicija počasna ali pa se še ni začela (Mastny, 1992). Svoboda izražanja, svoboda političnega delovanja in z njim povezana izvedba svobodnih in nepristranskih volitev, spoštovanje človekovih pravic in svoboda medijskega prostora so bili najpomembnejši kazalci politične tranzicije. Najpomembnejši kazalci ekonomske tranzicije pa so bili hitrost uvajanja tržnega gospodarstva, privatizacija državnih podjetij in odprtost za tuje investicije.

Glede na ta merila se je že zelo zgodaj izločila višegrajska trojka - Poljska, Madžarska in Češkoslovaška - kjer je tranzicijski proces potekal najhitreje. Na drugi strani so bile države, nastale na ozemlju nekdanje Jugoslavije, in Albanija, kjer je prehod v tržno gospodarstvo in demokracijo skoraj popolnoma zastal. ${ }^{10}$ Romunijo, Bolgarijo in baltske države so sicer prištevali k uspešnejšemu delu, vendar zaradi počasnejše tranzicije in slabših ekonomskih in političnih razmer niso bile nikoli postavljene v ospredje.

S poglabljanjem bilateralnih odnosov med Evropsko unijo in posameznimi državami je v geopolitični diskurz Unije prišel nov termin - pridružene države članica (ang. associated countries). S tem terminom so označevali države, skaterimi je imela Unija sklenjene asociacijske oziroma evropske sporazume (ang. Europe agreements). Podpis omenjenega sporazuma je potrjeval uspešnost tranzicijskega procesa v določeni državi, hkrati pa ji je omogočil vložitev uradne prošnje za polnopravno članstvo v Uniji. ${ }^{11}$ Države višegrajske skupine (Poljska, Madžarska in Češkoslovaška ${ }^{12}$ ) so omenjeni sporazum podpisale prve, in sicer že decembra 1991. V začetku leta 1993 je bil podpisan sporazum z Bolgarijo in Romunijo, junija 1995 z baltskimi državami in junija $1996 \mathrm{~s}$ Slovenijo.

\footnotetext{
${ }^{9}$ Omenjeno tezo zagovarja Francis Fukuyama v knjigi The End of History and the Last Man (Fukuyama, 1992).

${ }^{10} \mathrm{~V}$ to skupino so do leta 1993 uvrščali tudi Slovenijo.

${ }^{11}$ Na srečanju Evropskega sveta v Kobenhavnu junija 1993 je bila državam s sklenjenim asociacijskim sporazumom prvič jasno dana obljuba o možnosti polnopravnega članstva v Uniji. Hkrati je bilo izrecno navedeno, da članstvo v Uniji ni omejeno na države z že sklenjenimi asociacijskimi sporazumi, ampak zanj lahko zaprosijo tudi države, s katerimi bodo pridružitveni sporazumi sklenjeni v prihodnosti. (Glej: European Council 1993a)

${ }^{12}$ Po razdelitvi države je Evropska unija oktobra 1993 s Češko in Slovaško sklenila ločena sporazuma.
} 
Asociacijski sporazumi so pomembno pripomogli k preoblikovanju geopolitične podobe vzhodnega dela celine. Čeprav je med podpisom prvega in zadnjega minilo več kot štiri leta, so bile že sredi leta 1994 jasno izoblikovane nove meje v nekdanji Vzhodni Evropi. Regija se je dokončno razdelila na "zmagovalke" in "poraženke" tranzicije.

Prvi tabor so sestavljale države Srednje in Vzhodne Evrope. Vodilni položaj v njem je pripadel državam višegrajske skupine - Poljski, Češki, Slovaški in Madžarski, poleg njih pa so bile v njem še Romunija, Bolgarija, Slovenija in baltske države. Čeprav so Slovenija in baltske države pridružitvene sporazume sklenile relativno pozno, jih je Evropska unija že prej štela za del "zmagovitega" tabora. ${ }^{13} \mathrm{Z}$ njim so se dokončno rešile umeščenosti v prostor nekdanje Sovjetske zveze oziroma nekdanje Jugoslavije ter z njo povezane negativne podobe.

V tabor "poraženk" so bile uvrščene Albanija in države nastale na ozemlju nekdanje Jugoslavije, z izjemo Slovenije. Predvsem slednje so zaradi vpletenosti v spopade (Hrvaška, Bosna in Hercegovina, Zvezna Republika Jugoslavija) ter potencialnih žarišč na njihovem ozemlju (Zvezna republika Jugoslavija, Makedonija) veljale za zgled "neevropskosti".

Negativen odnos Evropske unije do držav, nastalih na območju nekdanje Jugoslavije, je delno povezan tudi z neuspešnim poskusom reševanja krize. Razpad Jugoslavije je potekal sočasno $\mathrm{z}$ oblikovanjem skupne zunanje in varnostne politike (CFSP - Common Foreign and Security Policy). Kriza je bila njen prvi resnejši preizkus. Mnogi so v njej videli odlično priložnost za dokazovanje in uveljavitev Unije na globalnem političnem prizorišču. Luksemburški zunanji minister Jacques Poos je govoril o "uri Evrope" ("the hour of Europe has dawned") (Silber \& Little, 1996). Z uspešno rešitvijo krize naj bi Evropska unija dokazala, da ni le pomemben gospodarski subjekt, temveč tudi upoštevanja vredna politična sila.

Sprva se je zdelo, da bo Uniji uspelo zaustaviti krizo, saj je uspešno posredovala pri sporazumu o končanju spopadov v Sloveniji. Zapletlo pa se je na Hrvaškem in v Bosni in Hercegovini, kjer se je njen pristop izkazal za popolnoma neprimernega. Vztrajanje pri reševanju krize z diplomatskimi sredstvi (pogajanji) ter enačenju odgovornosti vseh vpletenih strani ni prineslo uspeha.

Neuspeh pogajanj je utrdil stališče, da gre $\mathrm{v}$ Jugoslaviji za starodaven etnični konflikt, ki je tako zapleten, da ga je nemogoče rešiti. ${ }^{14}$ Območje je po mnenju J. Delorsa (1992) zajela "usodna nalezljiva bolezen", za katero so značilni ultra nacionalizem, obsedenost z željo po neodvisnosti (za vsako ceno), obsedenost $\mathrm{z}$ etnično čistostjo, morilska strast in nezmožnost toleriranja drugih etničnih in verskih skupin. Medtem ko je "Evropa" zagovarjala povezovanje, demokracijo, pluralnost, strpnosti in multikulturalizem, je bila omenjena regija zapletena v nevarne medetnične in verske konflikte, ki naj bi bili del preteklosti. Zgled Unije tu ni bil dovolj za začetek procesa politične in gospodarske tranzicije, potrebno bi bilo odločno

\footnotetext{
${ }^{13}$ Evropska Unija je že na Evropskem svetu v Kobenhavnu junija 1993 poudarila, da je eden od njenih ciljev čim prejšnja sklenitev Evropskih sporazumov z Baltskimi državami (European Council, 1993). Enako je na Evropskem svetu na Krfu junija 1994 izrazila pripravljenost na utrditev odnosov s Slovenijo (European Council, 1994). Glej tudi Interim report from the Commission to the European Council on the effects on the policies of the European Union of enlargement to the associated countries of Central and Eastern Europe (European Commission, 1995).

${ }^{14}$ Zahodno vojaško posredovanje bi lahko pripeljalo do novega Vietnama, Severne Irske, Alžirije, Libanona (Ó Tuathail, 1996; Simms, 2001).
} 
posredovanje, ki pa ga Unija zaradi notranjih nasprotij ni bila zmožna izvesti. Države na območju nekdanje Jugoslavije se niso bile sposobne oziroma se niso želele "vrniti k Evropi". Ostale so zunaj "Evrope", zaradi politične, kulturne in gospodarske drugačnosti so postale "neevropski”" del Evrope.

\section{3 “Ura Evrope” drugič}

Vojna na območju nekdanje Jugoslavije je zunanjepolitičnim ambicijam Evropske unije zadala močan udarec. Pokazala je, da je Evropska unija v primerjavi z ZDA pravi politični palček in da njena politična moč močno zaostaja za gospodarsko močjo. Velika ambicija - postati enakovredni partner ZDA, ne samo na gospodarskem, temveč tudi na političnem področju - se ni uresničila. Izkazalo se je, da Unija ni sposobna enotno in odločno posredovati niti na evropskem kontinentu, kaj šele drugje po svetu, ter da ob koncu 20. stoletja ZDA ostajajo edina globalna velesila. Daytonski mirovni sporazum je bil najboljši dokaz njene nemoči in nepomembnosti. Evropska unija ni imela vidnejše vloge pri implementaciji sporazuma. ${ }^{15}$

Ponižanje, ki ga je Unija doživela v Bosni in Hercegovini, se je odražalo v geopolitičnih diskurzih. Številni evropski politiki so opozarjali na pomanjkljivosti skupne zunanje politike. ${ }^{16}$ Očitno je bilo, da mora Unija, če želi imeti pomembno vlogo na mednarodnem političnem prizorišču, reformirati skupno zunanjo in varnostno politiko ter opredeliti prednostne zunanjepolitične cilje. Sprejem Amsterdamske pogodbe oktobra 1997 je dal nov zagon zunanjepolitičnim ambicijam Evropske unije. Z njo so bili oblikovani nekateri novi instrumenti, ${ }^{17}$ ki naj bi omogočali hitrejše, učinkovitejše in bolj usklajeno delovanje.

Srednja in Vzhodna Evropa sta tudi po sprejetju Amsterdamske pogodbe ostali v središču zunanjepolitičnih ambicij Unije. Zaradi fiaska z začetka devetdesetih let je Unija postala previdnejša pri razglašanju zunanjepolitičnih ambicij, poleg tega se je spremenil tudi način delovanja. Uveljavila se je politika postopnih korakov, s katero je Unija počasi večala svojo vlogo v regiji.

Velike razlike v političnih, gospodarskih in družbenih razmerah v Srednji in Vzhodni Evropi so botrovale oblikovanju dveh različnih pristopov. Države, ki so do začetka leta 1997 vložile prošnjo za članstvo, so bile leta 1997 vključene v širitveni proces, katerega končni cilj je bilo polnopravno članstvo v Evropski uniji. Na drugi strani so bile države, nastale na območju nekdanje Jugoslavije, in Albanija, vključene v t.i. Regionalni pristop. Le-ta je na eni strani spodbujal sodelovanje med posameznimi državami in Evropsko unijo, na drugi pa si je

\footnotetext{
${ }^{15}$ Vloga Evropske unije je bila omejena na zbiranje in koordiniranje pomoči za obnovo.

${ }^{16}$ Eden najaktivnejših zagovornikov sprememb skupne zunanje in varnostne politike je bil Hans van den Broek komisar, pooblaščen za zunanje odnose, ki je v svojih govorih pogosto opozarjal na nezmožnost članic, da bi nacionalne interese podredile skupnim ciljem (glej van den Broek, 1994, 1995, 1996).

${ }^{17}$ Unija je imenovala visokega predstavnika za skupno zunanjo in varnostno politiko (High Representative for the CFSP). Ustanovljena je bila enota za načrtovanje politike in zgodnje opozarjanje (The policy planning and early warning unit). Unija je določila, da morajo države članice zagotoviti vojaške enote za izvajanje t.i. nalog Petersberg. Poleg tega pogodba omogoča možnost integracije Zahodnoevropske unije (Western European Union) v Evropsko unijo.
} 
prizadeval za večje gospodarsko in politično sodelovanje v Jugovzhodni Evropi. Končni cilj obeh pristopov je bil širitev zahodne politične, gospodarske in družbene ureditve v Srednjo in Vzhodno Evropo oziroma vrnitev omenjenih držav v "Evropo".

Nove razmere so zahtevale novo prostorizacijo Srednje in Vzhodne Evrope, predvsem njenega južnega dela. Daytonski mirovni sporazum je prinesel novo upanje v boljšo prihodnost tega dela Evrope. Oznaki nekdanja Jugoslavija ${ }^{18}$ in Balkan ${ }^{19}$, ki sta bili zaznamovani z negativno konotacijo, so začeli opuščati, oziroma nadomeščati s terminom Jugovzhodna Evropa. ${ }^{20}$ Jugovzhodna Evropa ni bila več območje starodavnih etničnih in verskih spopadov, temveč je bila na poti, da postane del "Evrope". Politična in ekonomska stabilizacija regije je obljubljala počasno vključitev v "evropsko družino narodov".

Z geopolitičnega stališča je zanimivo, da je pojem Jugovzhodna Evropa geografsko veliko širši od pojma nekdanja Jugoslavija, saj vključuje tudi Albanijo, Romunijo in Bolgarijo. Medtem ko je nova oznaka pozitivno vplivala na odnos Evropske unije do držav, nastalih na ozemlju nekdanje Jugoslavije in Albanije, je dolgoročno negativno vplival na odnos do Romunije in Bolgarije. Njuno vključevanje v različne regionalne pobude (npr. Pakt stabilnosti za Jugovzhodno Evropo) je bil jasen znak prepočasnega poteka politične in gospodarske tranzicije ter zaostajanja za drugimi kandidatkami. Kljub temu je treba poudariti, da je Unija vse do leta 2001 Romunijo in Bolgarijo obravnavala enako kot druge kandidatke za članstvo.

\subsection{I Širitveni proces}

S podpisom pridružitvenega sporazuma s Slovenijo junija 1996 in oddajo še zadnjih prošenj za članstvo v Evropski uniji (Češka januarja 1996 in Slovenija junija 1996), so se začele resnejše priprave na širitveni proces. Evropska komisija je ugotovila, da nobena od kandidatk ne izpolnjuje vseh pogojev za vstop, določenih v Kobenhavnu, zato je v Agendi 2000 predlagala, da se države pred pogajanji razdelijo v dve skupini ${ }^{21}$ (Baron, 2002). Evropski svet je na zasedanju v Luksemburgu decembra 1997, sprejel omenjeno delitev ter določil, da se pogajanja s prvo skupino začno marca 1998 (Evropski svet 1997). Za države, vključene v drugo skupino, je bilo pomembno, da se je Unija odločila za t.i. regatni pristop (Baron, 2002). Trajanje in ritem pogajanj naj bi sproti prilagajali napredku v posameznih kandidatkah, zato so države lahko prehajale iz ene skupine v drugo (Evropski svet 1997, 1998, 2000). Sprva je

\footnotetext{
${ }^{18} \mathrm{Z}$ oznako države na območju nekdanje Jugoslavije ali pa nekdanja Jugoslavija (ang. ex-Yugoslavia) so označevali Hrvaško, Bosno in Hercegovino, Zvezno republiko Jugoslavijo in Makedonijo. Slovenija je že zelo zgodaj (19921993 ) izstopila iz te skupine.

${ }^{19}$ Z uvedbo temina Jugovzhodna Evropa termin Balkan ni popolnoma izginil iz dokumentov Evropske unije.

${ }^{20}$ Pojem Jugovzhodna Evropa je bil v dokumentih Evropske unije prvič omenjen junija 1996, in sicer v sklepih Evropskega sveta v Lyonu (European Council, 1996).

${ }^{21}$ Prvo skupino so sestavljali Ciper, Češka, Estonija, Madžarska, Poljska in Slovenija, drugo pa Bolgarija, Latvija, Litva in Romunija. Slovaška zaradi težav pri uvajanju demokratične ureditve sprva ni bila vključena $\mathrm{v}$ nobeno skupino, kasneje je bila uvrščena v drugo (Baron, 2002).
} 
Evropska komisija ocenjevala napredek posameznih držav glede na število odprtih poglavij ${ }^{22}$ v pogajanjih, pozneje pa glede na število zaprtih oziroma zaključenih poglavij. Zaradi hitrega napredka pri pogajanjih z državami iz druge skupine - pristopna pogajanja z njimi so se začela februarja 2000 - je delitev na dve skupini kmalu postala nesmiselna. Konec leta 2001 je bilo jasno, da samo Romunija in Bolgarija nista sposobni slediti tempu drugih kandidatk ter da jima ne bo uspelo končati pogajanj do konca leta 2002 (Evropski svet 2001b). Na evropskem vrhu v Kobenhavnu je odločeno, da bodo Ciper, Češka, Estonija, Latvija, Litva, Malta, Madžarska, Poljska, Slovaška in Slovenija, 1. maja 2004 postali polnopravni člani Evropske unije. Obenem se je Evropska unija zavezala, da bo nadaljevala pogajanja z Romunijo in Bolgarijo, ki naj bi postali članici predvidoma leta 2007 (Evropski svet 2002).

Skladno s potekom pogajanj se je spreminjala tudi prostorizacija Srednje in Vzhodne Evrope (Slika 2). Z začetkom pristopnih pogajanj se je spremenilo tudi označevanje držav v Srednji in Vzhodni Evropi. Termin pridružene države (ang. associated countries) je nadomestil termin države kandidatke (ang. candidate countries). Z njim so označevali vse države, ki so bile vključene v pristopna pogajanja. Širitveni proces je vplival tudi na podobo posameznih kandidatk. Države višegrajske skupine, ki so na začetku devetdesetih veljale za zgled preostalim tranzicijskim državam, so zaradi velikega napredka baltskih držav in Slovenije izgubile vodilni položaj.

\subsubsection{Regionalni pristop ter Stabilizacijski in asociacijski proces}

Države južnega dela Srednje in Vzhodne Evrope, po novem imenovane Jugovzhodna Evropa, zaradi počasne tranzicije niso bile vključene $\mathrm{v}$ širitveni proces (izjema sta bili Romunija in Bolgarija). Izkušnja iz preteklosti - vojna v Bosni in Hercegovini je pokazala, da lahko navidezno nepomembni konflikti na obrobju destabilizirajo celoten kontinent - so prepričale evropske politike, da regija ne sme biti prepuščena sama sebi ter da mora Unija aktivno posegati v dogajanje. Takšno razmišljanje je aprila 1997 pripeljalo do sprejetja tako imenovanega Regionalnega pristopa [Regional approach] do držav Jugovzhodne Evrope. Z njim je Evropska unija želela povečati sodelovanje med posameznimi državami in Unijo ter okrepiti meddržavno sodelovanje znotraj regije. Vanj so bile vključene države, s katerimi Unija ni imela sklenjenega evropskega oz. asociacijskega sporazuma. ${ }^{23}$

Glavni namen Regionalnega pristopa je bil povečati sodelovanje na političnem, ekonomskem in kulturnem področju, s čimer naj bi zmanjšali možnost izbruha novih kriz in spopadov. Posebna pozornost je bila namenjena promociji demokracije, vladavine prava, človekovih pravic in pravic manjšin. V ta namen je Unija namenila znatna sredstva s katerimi so financirali programe, ki so podpirali zgoraj naštete cilje. Za Regionalni pristop je značilna politika korenčka in palice. Državam so bili postavljeni določeni politični in ekonomski

\footnotetext{
${ }^{22}$ Prva skupina držav je že v času portugalskega predsedovanja Uniji (prva polovica leta 2000) začela pogajanja na vseh področjih z izjemo "Institucije" (European Council, 2000), medtem ko je drugi skupini to uspelo na sredini leta 2001 (European Council, 2001a).

${ }^{23}$ V Regionalni pristop so bile vključene Hrvaška, Bosna in Hercegovina, Zvezna republika Jugoslavija, Makedonija in Albanija.
} 
Karta 2: Prostorizacija Srednje in Vzhodne Evrope v dokumentih Evropske unije v obdobju 19972005.

Figure 2: Spatialization of Central and Eastern Europe in the documents of European Union from 1997 till 2005.

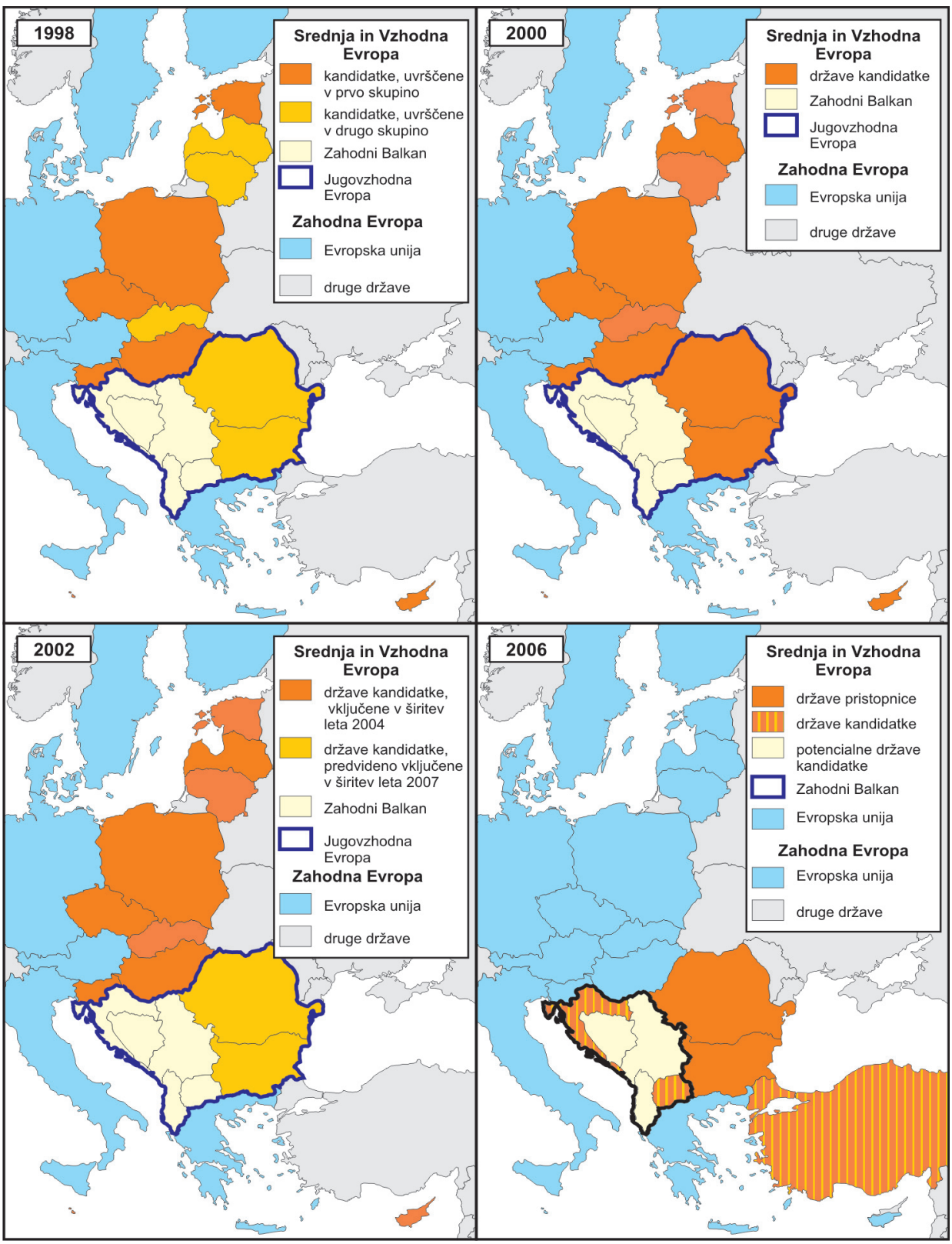


pogoji, od njihovega izpolnjevanja pa so bili odvisni bilateralni odnosi z Unijo. Države so bile deležne različnih trgovinskih ugodnosti, finančne pomoči (sodelovanje v programu PHARE, kasneje CARDS) ter ugodnosti v pogodbenih odnosih z Unijo (Bulletin EU, 1997).

Kmalu po sprejetju nove politike je v geopolitičnih diskurzih Unije nastal nov termin Zahodni Balkan ${ }^{24}$ (Slika 2). Z njim so označevali države vključene v Regionalni pristop. Uvedba novega termina je bila potrebna ker sta bila termina Jugovzhodna Evropa in bivša Jugoslavija neustrezna. Prvi je obsegal tudi Romunijo in Bolgarijo, ki sta bili v odnosih z Unijo daleč pred drugimi državami v regiji in nista bili vključeni v Regionalni pristop. Drugi je bil neustrezen iz več razlogov. Na eni strani je bil nabit z negativno konotacijo - večina ga je povezovala z vojno, etničnim nasiljem, vojnimi zločini itd. Poleg tega je bila nekdanja Jugoslavija temna lisa v zunanji politiki Evropske unije. Na njenem ozemlju so se razblinile sanje evropskih politikov o enotni zunanji in varnostni politiki, ki bi Evropsko unijo postavila ob bok Združenim državam Amerike. Nov termin naj bi simboliziral novo prenovljeno zunanjo politiko - kar Uniji ni uspelo v nekdanji Jugoslaviji, naj bi ji na Zahodnem Balkanu. Prostorsko gledano je bil nov termin potreben zato, ker je oznaka nekdanja Jugoslavija vključevala Slovenijo (ki ni bila vključena v Regionalni pristop), izključevala pa je Albanijo (ki je bila vključena v Regionalni pristop). Poleg naštetega je treba opozoriti na praktični vidik uporabe termina Zahodni Balkan. Že prej smo razložili, zakaj termini Jugovzhodna Evropa, nekdanja Jugoslavija in Balkan niso ustrezni. Nepraktičen je tudi termin nekdanja Jugoslavija minus Slovenija plus Albanija, da o nesmiselnosti termina Zahodna Jugovzhodna Evropa sploh ne govorimo. Termin Zahodni Balkan je tako "politično korekten", hkrati pa tudi praktičen. Drugače povedano, Zahodni Balkan označuje ozemlje Albanije, Bosne in Hercegovine, Hrvaške, Makedonije in Zvezne republike Jugoslavije oz. Srbije in Črne gore, ni zaznamovan $\mathrm{z}$ bremenom tamkajšnjega dogajanja $\mathrm{v}$ preteklosti, ne spominja na prve neuspešne začetke skupne zunanje in varnostne politike Evropske unije in je obenem priročen.

Razvoj političnih dogodkov je na novo oblikovano politiko takoj postavil pred resno preizkušnjo. Zahodni Balkan je med letoma 1997 in 2002 doživel številne pozitivne in negativne pretrese, ki so opozorili da je nujna nadgradnja oziroma poglobitev politike Regionalnega pristopa. Nemiri v Albaniji, izbruh kosovske krize, padec Miloševićevega režima v Zvezni republiki Jugoslaviji, zamenjava nacionalistične HDZ-jevske oblasti na Hrvaškem, izboljšanje varnostnih in političnih razmer v Bosni in Hercegovini ter izbruh etničnih spopadov v Makedoniji so le najpomembnejši dogodki, ki so vplivali na politiko Unije do Zahodnega Balkana.

Evropska Unija je aktivno posegla $\mathrm{v}$ dogajanje ter $\mathrm{s}$ svojo politiko pripomogla $\mathrm{k}$ stabilizaciji regije in napredku tako na ekonomskem kot političnem področju. S prevzemom

\footnotetext{
${ }^{24} \mathrm{~V}$ dokumentih iz let 1996 in 1997 je govor o Regionalnem pristopu Evropske unije do držav Jugovzhodne Evrope (glej Bulletin EU, 1997). Termin Zahodni Balkan prvič najdemo v izjavi za javnost z dne 26. 1. 1998. (PRES/98/13 - 2066th Council meeting GENERAL AFFAIRS). V dokumentih Evropskega sveta se prvič uporabi decembra 1998 na dunajskem vrhu (European Council, 1998b).
} 
vodilne vloge $\mathrm{v}$ Bosni in Hercegovine, ${ }^{25}$ pomočjo pri zagotavljanju humanitarne pomoči kosovskim beguncem, aktivnim sodelovanjem pri obnovi Kosova in ustavitvijo etničnih spopadov v Makedoniji ji je uspelo povečati svoj ugled in samozavest. Izkazalo se je, da lahko odigra pomembno vlogo na mednarodnem prizorišču. Zahodni Balkan je poleg širitve v Srednjo in Vzhodno Evropo postal vzorčen primer učinkovitosti skupne zunanje in varnostne politike Evropske unije. Pomenil je "evropski" način urejanje mednarodnih odnosov, ki je temeljil na multilateralizmu in uporabi "mehke varnosti" [soft security], ki promovira dobro vladanje, spodbuja ekonomski razvoj in se bojuje proti revščini (glej Prodi, 2004).

Evropska unija je postala "zvezda vodnica", in to ne samo državam Srednje in Vzhodne Evrope, ampak celotnemu svetu. Razvite države naj bi se po njej zgledovale pri zagotavljanju razvojne in humanitarne pomoči ter zagovarjanju multilateralizma v mednarodni politiki. Nerazvitim državam in problematičnim regijam pa naj bi bila zgled, kako je mogoče odpraviti nesoglasja, kako lahko s sodelovanjem in sprejemanjem različnosti vsi pridobijo.

"Združena Evropa" je ponovno postala zgodovinska naloga in najpomembnejši zunanjepolitični cilj Evropske unije (glej Patten, 2001). Skladno s tem ciljem je bilo treba preoblikovati Regionalni pristop. Unija je potrebovala novo celovito, koherentno politiko do Jugovzhodne Evrope oziroma Zahodnega Balkana. Maja 1999 je Evropska komisija predlagala oblikovanje Stabilizacijskega in asociacijskega procesa [Stabilisation and Association Process (SAP)] (Evropska komisija, 1999), ki je nadgradnja Regionalnega pristopa in je oblikovan na izkušnjah, pridobljenih v širitvenem procesu. Prek SAP naj bi se države Zahodnega Balkana postopoma vključile v Evropsko unijo, njegov končni cilj je polnopravno članstvo omenjenih držav v Uniji. Slednjo obljubo je potrdil tudi Evropski svet na srečanju v Feiri junija 2000, ko je sklenil, da so vse države, vključene v Stabilizacijski in asociacijski proces, potencialne kandidatke za članstvo v Evropski uniji (Evropski svet 2000).

\section{ZDRUŽENA EVROPA?}

Evropo so v zadnjih dvajsetih letih zaznamovali številni procesi, ki so radikalno spremenili podobo celine. Gospodarska in politična tranzicija, integracijski procesi v okviru Evropske unije in dezintegracija nekaterih držav so ustvarili novo politično stvarnost, ki je različne akterje prisilila k preoblikovanju ustaljenih predstav o svetu in redefiniciji lastnih vlog. Evropska unija je svojo vlogo našla v povezovanju "Evrope" oziroma vrnitvi držav Srednje in Vzhodne Evrope v “evropsko družino narodov”. Z njeno pomočjo naj bi se Vzhodna Evropo "evropeizirala" ter postala "prava Evropa". Polnopravno članstvo v Evropski uniji naj bi bil končni cilj omenjenega procesa ter dokaz "evropskosti”.

Proces "vrnitve" ni potekal povsod enako hitro. Medtem ko je v severnem delu Srednje in Vzhodne Evrope potekal relativno neproblematično, je v južnem naletel na številne

\footnotetext{
${ }^{25}$ Hitra in relativno neproblematična implementacija vojaškega dela Daytonskega mirovnega sporazuma je omogočila mednarodni skupnosti, da se je osredotočila na civilni del sporazuma. Ta premik je spremenil odnose med različnimi mednarodnimi akterji. ZDA, ki so imele glavno vlogo pri implementaciji vojaškega dela, so morale glavno besedo prepustiti organizacijam, odgovornim za implementacijo civilnega dela. Zaradi velikih sredstev, vloženih v obnovo, je Evropski uniji pripadla vodilna vloga pri nadaljnjem razvoju države.
} 
težave. Velike razlike med državami so Evropsko unijo prisilile k oblikovanju dveh različnih modelov "vrnitve". Uspešnejše države so bile vključene v širitveni proces, manj uspešne pa v Stabilizacijski in asociacijski proces. Končni cilj obeh je enak, polnopravno članstvo v Evropski uniji. Osem držav (Estonija, Češka, Litva, Latvija, Madžarska, Poljska, Slovaška, Slovenija) je cilj dosegla 1. maja 2004, Romunija in Bolgarija naj bi ga dosegli leta 2007, datum vključitve preostalih držav je še nejasen. Kljub temu je pomembno, da se omenjene države obravnavajo kot potencialne kandidatke za članstvo oziroma za del "Evrope".

Evropska unija uporablja proces "združevanja Evrope" za utrjevanje lastne identitete. Ta pomembni vidik zunanje politike se pogosto zanemarja. Evropska unija je s širitvenim procesom poskušala odgovoriti na vprašanje: Kaj je Evropa? Potencialne članice so morale izpolniti številne pogoje, če so želele postati del "Evrope". Seveda je bilo samoumevno, da države, ki so že v "Evropi”, vse postavljene pogoje izpolnjujejo. Povedano drugače, če Unija od potencialnih kandidatk zahteva, da morajo imeti demokratično ureditev, tržno gospodarstvo, da morajo spoštovati človekove pravice ter pravice manjšin itd., to hkrati pomeni, da obstoječe članice omenjene pogoje že izpolnjujejo. Številni primeri v našem sosedstvu pa dokazujejo, da $\mathrm{v}$ resnici ni tako.

Vključevanje držav Srednje in Vzhodne Evrope v Evropsko unijo, slednja uporablja za definiranje in uveljavljanje lastne vloge $v$ svetu. Z njim poskuša svetu pokazati, da je pomemben globalni akter, katerega politika se občutno razlikuje od tradicionalnih politik svetovnih velesil. S promoviranjem multilateralizma, reševanjem konfliktov z diplomatskimi sredstvi ter uporabo t.i. mehke (nevojaške) sile želi postati zgled preostalim akterjem v mednarodni politiki. Hkrati so doseganje konsenzov, sklepanje kompromisov in nenasilno reševanje konfliktov eden pomembnih temeljev "evropske" identitete.

Stranski produkt "vrnitve v Evropo" je oblikovanje novih meja Evrope, natančneje oblikovanje nove vzhodne meje Evrope. Evropska unija je s pomočjo širitvenega procesa ter Stabilizacijskega in asociacijskega procesa določila, do kod sega Evropa. Medtem, ko je v času hladne vojne meja "prave Evrope" potekala od Szczecina do Trsta, se je zdaj prestavila na vzhodno mejo Estonije, Latvije, Litve, Poljske, Slovaške, Madžarske in Romunije. Države vzhodno od te meje so izključene iz "Evrope". Da Evropa sega le do tod, potrjuje že ime politike, ki jo je Evropska unija oblikovala do omenjenih držav - politika evropske soseščine [European Neighbourhood Policy]. V skladu s to politiko so Belorusija, Ukrajina, Moldavija in Rusija "evropska soseščina" in ne del "Evrope". ${ }^{26}$

Na koncu je treba še enkrat opozoriti, da je Evropska unija projekt političnih elit. Čeprav je minilo že več kot petnajst let od padca železne zavese in se v Evropski uniji namesto o Vzhodni Evropi govori o Srednji in Vzhodni Evropi, novih članicah, državah pristopnicah, državah kandidatkah, Zahodnem Balkanu itd, je v zavesti ljudi Vzhodna Evropa še vedno močno prisotna. Ponovno se moramo strinjati z Debeljakom (2004, str. 9) ko pravi: Evropske politične in gospodarske elite se ne morejo izogniti dejstvu, da je zahodna Evropa še vedno "družina zase", ločena od ostale celine, in to navzlic odgrnjeni železni zavesi, koncu hladne vojne in zrušitvi komunističnih despotizmov.

\footnotetext{
${ }^{26}$ Zelo zanimiv je položaj Turčije, ki je vključena v širitveni proces, vendar je njeno članstvo v Uniji zelo negotovo, saj je mnogi ne priznavajo za del Evrope.
} 
Številni indici kažejo, da bo ravno trdovratna zasidranost hladno vojne delitve na Vzhod in Zahod, ki je zakoreninjena v Zahodni Evropi, močno vplivala na prihodnje prostorizacije Srednje in Vzhodne Evrope. Za dokončno "vrnitev k Evropi” ne bo dovolj le oblikovati nove termine, potrebna bo temeljita sprememba miselnosti v Zahodni Evropi. Dokler bo poljski vodovodni inštalater predstavljal veliko grožnjo večini prebivalcev v Zahodni Evropi, je vsako govorjenje o "združeni Evropi" brezpredmetno leporečje. Pred evropolitiki je pomembna naloga, novo prostorizacijo Evrope morajo "prodati” lastnim državljanom, pri tem pa morajo na eni strani umiriti strahove prebivalstva obstoječih članic, na drugi pa izpolniti pričakovanja potencialnih bodočih članic.

\section{Viri in literatura}

Andreson, B., 2003. Zamišljene skupnosti - O izvoru in širjenju nacionalizma. Ljubljana, Studia Humanitatis, str. 225.

Barón, E., 2002. Evropa na pragu novega tisočletja. Ljubljana, Vale Novak, str. 276.

Barroso, J. M., 2005. Solidarity as a foundation for European integration. Speech to the conference: Solidarnosc to Freedom (30. 8. 2005), SPEECH/05/467 http://europa.eu.int/ $\mathrm{rapid} / \mathrm{set}$ Language.do?language $=$ en (citirano: 8.2.2006)

Berzin M. in Schain M. Europe without Borders - Remapping Territory, Citizenship, and Identity in a Transnational Age. London, Johns Hopkins University Press, str. 317.

Berzin, M., 2003. Territory, Emotion, and Identity - Spatial Recalibration in a New Europe. v Berzin M. in Schain M., Europe without Borders - Remapping Territory, Citizenship, and Identity in a Transnational Age. London, Johns Hopkins University Press, str. 1-30.

Boden, M., 2004. Evropa: naša preteklost in sedanjost. Ljubljana, Založba Mladinska knjiga, str. 585.

van den Broek, H., 1994. Speech of Hans van den Broek - 30th Anniversary of the institute for European Studies (Brussels, 17.3.1994). SPEECH/94/25. http://europa.eu.int/rapid/ setLanguage.do?language $=\mathrm{en}$ (citirano: 8.2.2006)

van den Broek, H., 1995. The Common Foreign and Security Policy: The Challenges of the Future"Europees InstituutvoorBestuurskunde(Maastricht 19.10.1995). SPEECH/95/215. http://europa.eu.int/rapid/setLanguage.do?langu age=en (citirano: 8.2.2006)

van den Broek, H., 1996. Towards a Wider and Stronger Europe - Hans van den Broek - The Finnish Confederation of Industry (Helsinki, 31.5.1996) SPEECH/96/142. http://europa. eu.int/rapid/setLanguage.do?language=en (citirano: 8.2.2006)

Bulletin EU, 1997. Council conclusions on the principle of conditionality governing the development of the European Union's relations with certain countries of south-east Europe (1/1). Bulletin EU št. 4, ECSC-EC-EAEC, Bruselj, http://europa.eu.int/ abc/doc/ off/bull/en/9704/p202001.htm (citirano: 8.2.2006)

Campbell, D., 1998. Writing security - United States Foreign Policy and Politics of Identity. Minneapolis, University of Minnesota Press, str. 290.

de Clercq W., 1987. The Community and Eastern Europe: Economic and trade relations - speech by mr. Willy de Clercq., Copenhagen 17. July 1987. http://europa.eu.int/rapid/ setLanguage.do?language $=$ en (citirano: 8.2.2006) 
Cohen, S.B., 1973. Geography and politics in a world divided (2nd edition). New York, Oxford University Press, str. 334.

Debeljak, A., 2004. Evropa brez Evropejcev. Ljubljana, Založba Sophia, str. 219.

Dodds, K., 2005. Global Geopolitics - A Critical Introduction. Edinburgh, Pearson Education Limited, str. 254.

Delors, J., 1992. Speech of President Delors at the Special session of European Parliament Committees on the former Yugoslavia (Brussels, 10. 8. 1992), SPEECH/92/77 Date: 10/08/1992, http://europa.eu.int/rapid/setLanguage.do? language=en (citirano: 8.2.2006)

Evropska komisija, 1992a. Europe and the challenge of enlargement - Prepared for the European Council Lisbon (26-27 June 1992), Bulletin of the European Communities Supplement 3/92. Brussels-Luxembourg, Office for Official Publications of the European Communities, str. 24.

Evropska komisija, 1992b. Towards a closer asaociation with the Countries of Central and Eastern Europe - Prepared for the European Council Edinburgh (11-12 December 1992), SEC(92) 2301. http://europa.eu.int/rapid/setLanguage.do? language=en (citirano: 18.3.2006)

Evropska komisija, 1992c. Meeting of the ministers of foreign affairs of the European Community and the Visegrad Countries - Joint Statement (5. 10. 1992). 9033/92 (Presse 170), http://europa.eu.int/rapid/setLanguage.do? language=en (citirano: 10.3.2006)

Evropska komisija, 1995. Interim report from the Commission to the European Council on the effects on the policies of the European Union of enlargement to the associated countries of central and eastern Europe Report for the European Council Madrid, 15.-16. December, 1995. CSE (95) 605, Bruselj 06. 12. 1995 http://europa.eu.int/rapid/setLanguage.do? language=en (citirano: 10.3.2006)

Evropska komisija, 1999. Commison preposes a Stabilisation and Association process for countries of South-Eastern Europe, (Bruselj, 26. 5.1999) IP/99/350. http://europa.eu.int/ $\mathrm{rapid} / \mathrm{setLanguage}$.do? language=en (citirano: 18.3.2006)

Evropski svet 1989. Conclusions of the presidency on the Strasbourg European Council (8.9. December 1989). Reference: DOC/89/3 http://europa.eu.int/rapid/ setLanguage.do? language=en (citirano: 20.4.2006)

Evropski svet 1990a. Conclusions of the Rome European Council (27.-28. October 1990). Reference: DOC/90/5 http://europa.eu.int/rapid/setLanguage.do? language=en (citirano: 20.4.2006)

Evropski svet 1990b. Conclusions of the Rome European Council (14.-15. December 1990): Reference: DOC/90/6, http://europa.eu.int/rapid/setLanguage .do? language=en (citirano: 20.4.2006)

Evropski svet 1992. European Council in Lisbon: Conclusions of the presidency (26.-27. junij 1992): Reference: DOC/92/3, http://europa.eu.int/rapid/set Language.do? language=en (citirano: 20.4.2006)

Evropski svet 1993. European Council in Copenhagen: Conclusions of the presidency (21. - 22. junij 1993), Reference: SN 180/1/93 REV 1, http://europa. eu/european_council/ conclusions/index_en.htm (citirano: 20.4.2006) 
Evropski svet 1994. European Council at Corfu: Presidency Conclusions (24. - 25. junij 1994), ec/00150, http://europa.eu/european_council/conclusions/index_en.htm (citirano: 20.4.2006)

Evropski svet 1996. Lyon Summit - Chairman's Statement (Lyon, 29. 6. 1996) - Toward greater Security and Stability in a More cooperative world: Reference: DOC/96/4, http:// europa.eu/european_council/conclusions/index_en.htm (citirano: 20.4.2006)

Evropski svet 1997. Luxembourg European Council: Presidency Conclusions (12. - 13. December 1997), http://europa.eu/european_council/conclusions/ index_en.htm (citirano: 20.4.2006)

Evropski svet 1998. Cardiff European Council: Presidency Conclusions (15. -16. junij 1998), Reference: SN 150/1/98 REV 1 http://europa.eu/european_council/conclusions/ index en.htm (citirano: 20.4.2006)

Evropski svet, 1998b. Vienna European Council: Presidency Conclusions (11. -12. december 1998), http://europa.eu/european_council/conclusions/index_en.htm (citirano: 20.4.2006)

Evropski svet, 2000. Santa Maria da Feira European Council: Presidency Conclusions (19. -20 junij 2000), http://europa.eu/european_council/conclusions /index_en.htm (citirano: 20.4.2006)

Evropski svet, 2000b. Nice European Council meeting: Presidency Conclusions (7.- 9. december 2000), http://europa.eu/european_council/conclusions/index_en.htm (citirano: 20.4.2006)

Evropski svet, 2001a. Göteborg European Council: Presidency Conclusions (15. - 16 junij 2001), Reference: SN 200/1/01 REV 1, http://europa.eu/european_council/conclusions/ index_en.htm (citirano: 29.4.2006)

Evropski svet, 2001b. European Council meeting in Laeken: Presidency Conclusions (14. - 15 december 2001), Reference: 15917/02, http://europa.eu/european_council/conclusions/ index_en.htm (citirano: 29.4.2006)

Evropski svet, 2002. Copenhagen European Council: Presidency Conclusions (12. - 13 december 2002), Reference: SN 300/1/01 REV 1, http:// europa.eu/european_council/ conclusions/index_en.htm (citirano: 29.4.2006)

Fukuyama, F., 1992. The End of History and the Last Man. London, Penguin Books, str. 418.

Konrad, G., 1988. Antipolitika: Srednjeevropske meditacije. Ljubljana, Krt, str. 161.

Lorenci, J., 2005. Unija v časih rahljanja. Delo (07.10.2005) http:/www.delo.si/ index. php?sv_path=43,50\&id=3b722eda214cb0e7f159405ee236eb4304\&source=Delo (citirano: 8.2.2006)

Mally, I., 2005. Med geopolitično re-orientacijo in mednarodno integracijo: izbrani vidiki širjenja Evropske unije v Srednji Evropi: magistrsko delo, Ljubljana, Oddelek za geografijo, Filozofska fakulteta, str. 156.

Mastny V., 1992. The Historical East Cenral Europe After Communism. v Michta A., Prizel I., Postcommunist Eastern Europe: Crisis and Reform. New York, St. Martin's Press, str. $1-20$.

Ó Tuathail, G., 1994: (Dis)placing geopolitics: writing in the maps of global politics. Environment and Planning D: Society and Space 12, str. 525 - 546.

Ó Tuathail, G., 1996: Critical geopolitics. Minneapolis, University of Minnesota, str. 314. 
Ó Tuathail, G., Dalby, S.,Routledge, P., 1998: The Geopolitical Reader. London, Routledge, str 327.

O’Tuathail, G., Dalby, S., 1998: Rethinking geopolitics. London, Routledge, str. 333.

Paasi A., 2005. Remarks on Europe's Transforming Meta-geography. Geopolitics 10, št. 3, str. 580-585.

Patten C., 2001. The Rt Hon Chris Patten European Commissioner for External Relations European Commission statement at the Regional Conference for South Eastern Europe (Stability Pact) Regional Conference for South Eastern Europe Bucharest, 25 October $2001 \mathrm{http}: / /$ europa.eu.int/rapid/setLanguage .do?language=en (citirano: 8.2.2006)

Portal Evropske Unije, 2006. The common foreign and security policy: introduction http:// europa.eu.int/scadplus/leg/en/lvb/r00001.htm\#a19004 (citirano: 23.4.2006)

Prodi R., 2004. A stronger alliance in a changing world, ISPI, Milan, (20. 2. 2004) SPEECH/04/90 $\mathrm{http} / /$ europa.eu.int/rapid/setLanguage.do? language=en (citirano: 8.2.2006)

Rehn O., 2005. Europe at a Crossroads: Enlargement, Constitution and the Future of the EU. Speech to the Transatlantic Institute, Brussels, 20th June 2005 SPEECH/05/363 http:// europa.eu.int/rapid/setLanguage.do?language=en (citirano: 20.2.2006)

Silber, L., Little A., 1996. The Death of Yugoslavia. London, Penguin Books \& BBC Books, str. 400.

Simoniti, I., 1997. Uvod. v Parker, G., Zahodna geopolitična misel v dvajsetem stoletju. Ljubljana, Fakulteta za družbene vede, str. 274.

Simms, B., 2002. Unfinest Hour: Britain and the Destruction of Bosnia. London, Penguin Books, str. 463.

Tunjić. F., 2004. Vmesna Evropa: Konfliktnost državnih teritorialnih meja. Koper, Univerza na Primorskem, ZRS Koper, Zgodovinsko društvo za južno Primorsko, str. 469.

\section{BACK TO EUROPE - GEOPOLITICAL DISCOURSES ABOUT CENTRAL AND EASTERN EUROPE INSIDE INSTITUTIONS OF EUROPEAN UNION}

\section{Summary}

Critical geopolitics argues that geopolitics is not a neutral and objective practice of surveying global space, but a discursive practice through which different actors spatialize global space (O’Tuathail \& Dalby, 1998; O’Tuathail, 1996). This article focuses on how different institutions in the European Union have spatialized Central and Eastern Europe after the end of the Cold war.

The European continent went through tremendous changes in the last twenty years. During the Cold war Europe was divided into the Eastern and the Western half. Many in the West treated the Eastern part as an "un-European" part of Europe. It represented the European "other". This simple map was changed by the fall of the iron curtain and the processes that followed it. Political and economic transition, integration processes and disintegration of several states have constructed a new political reality. The new situation forced different actors 
into a reconstruction of their worldviews and redefinition of their own roles in the world. The EU was no exception.

Eastern Europe was in the center of new geopolitical ambitions of the EU. The new mission of the EU is to return the countries of Eastern Europe back to "Europe". To be able to return, countries had to go through political, social and economic transition. The pace of transition varied from country to country. While the process was carried out in a relatively unproblematic way in the northern part, it encountered numerous problems in the southern one. According to this, the EU developed two different approaches. The first group was included in an enlargement process whereas the second in a regional approach. The final goal of both was the same: a full membership in the European Union. In May 2004 eight states from Central and Eastern Europe reached this goal, Romania and Bulgaria are expected to become full members in 2007, while the integration of all other states is still unclear.

The European Union is using the integration of Eastern Europe into the "European family of nations" for the construction and consolidation of its identity and for affirmation of its own role on the global political scene. Through the enlargement process the EU is trying to answer the following questions: What is Europe? Who are Europeans? Where are the borders of Europe? ... On the other hand it wants to show the world that it is an important global player, whose politics is very different from the politics of traditional powers. By promoting multilateralism, a peaceful resolution of conflicts with diplomatic means and the use of "soft power", the EU wants to become a guiding star for other actors in world affairs.

New circumstances demanded new spatialization. Instead of Eastern Europe - which was not suitable anymore - a new term Central and Eastern Europe was introduced. The period between 1989 and 2005 was marked by different events and processes that forced the EU into a constant reshaping of the existing spatializations of Central and Eastern Europe. New labels such as associated countries, candidate countries, Southeastern Europe, Western Balkans... were introduced.

Today, more than fifteen years after the fall of the iron curtain, the EU spatialization divides Central and Eastern Europe into the EU member countries (the Czech Republic, Estonia, Hungary, Lithuania, Latvia, Poland, Slovakia and Slovenia), acceding countries (Bulgaria, Romania), candidate countries (Croatia, Macedonia, and Turkey) and potential candidate countries (Albania, Bosnia and Herzegovina, Serbia and Montenegro).

But we must not forget that this spatialization is a product of the so called euro-elites. The EU has been and still is a project of the European political and economic elites and they cannot escape the fact that for the majority of people in Western Europe, Eastern Europe still exists. The debate around the European constitution has shown that many people in France, the Netherlands and other western countries see Central and Eastern Europe as a threat to their way of living and as an underdeveloped region where their money is carelessly spent. For them Central and Eastern Europe still represent "the other" un-European part of Europe. Talking about a "united Europe" will be meaningless as long as a Polish plumber is seen as one of the biggest threats to the citizens of the old member states. Euro-politicians are facing a difficult challenge; they have to "sell" the new spatialization of Europe to the general public. 